\title{
Distributive Leadership and its Relationship to Organizational Commitment in Secondary Schools of Sarawak
}

\author{
Hu Kuok Hua \\ School of Educational Studies, University Science Malaysia, Malaysia \\ Ying-Leh Ling \\ Mathematics, Science and Computer Department, Polytechnic Kuching Sarawak, Malaysia
}

\begin{abstract}
This quantitative study aims to identify the influence of distributive leadership on the organizational commitment of teachers. A total of 317 secondary school teachers were selected as respondents randomly from 18 national secondary schools around Kuching city. The data of this study was collected using the combined questionnaire of the Distributed Leadership Readiness Scale and the Three-Component Model Employee Commitment Survey. The findings shown that there is no significant difference in the level of teachers' organizational commitment according to the gender of the teachers. In addition, the Pearson Correlation Test found a positive and significant relationship between the distributive leadership level and the organizational commitment of teachers in the school. This study has shown that leadership and principals' ability has an impact on school organization excellence. Therefore, the role of the teacher needs to be maximized according to the teacher's expertise so that organizational commitment can be improved.

Keywords: Distributive leadership; Commitment.
\end{abstract}

\section{Introduction}

Committed teachers can contribute to organizational effectiveness. They affect work performance, school achievement, and student progress (Billingsley and Cross, 1992). However, significant changes in national education have affected the ability of teachers to take on the challenges and choose to leave the organization. Leadership efficiency in designing, managing, and managing organizations in line with the change is strongly emphasized for the excellence of the organization. However, the expectation of transforming schools depends on the unusual leader being unrealistic and ineffective. In this case, Timperly (2005) has explained the idea of distributive leadership and the situation has begun to be a new framework in understanding the reality of school supplies and its improvement. Hence, the direction of organizational leadership today has changed and no longer see the principal as the only individual who assumes total responsibility. This does not mean that school leaders assign all tasks to a specific individual or group but rely on one another to act more effectively. Elmore (2000), also described the leadership of more than one involving an integrated collaboration among members of the organization with different areas of expertise. The influence of distributive leadership on the success of the organization is not a heroic leader that makes the organization functioning well, on the other hand, factors affecting organizational effectiveness include expert competence, organizational initiatives initiatives, same direction based on trust, collective effort and coordination of strong organizational members (Ingvarson et al., 2006). In other words, the distributive leadership approach provides a tendency for followers and leaders to work together at school (Gronn, 2000). Distributive leadership provides the opportunity for teachers to engage in decision-making. It is more lateral and less hierarchical in the way the staff works (Harris and Spillane, 2008). In addition, distributive leadership promotes social interaction between leaders and followers and social interactions that contribute significantly to increased teacher commitment, teacher effectiveness and student engagement (Leithwood and Jantzi, 2000). Therefore, this study is aimed at identifying the significant relationship between distributive leadership and organizational commitment among teachers especially in the city of Kuching, Sarawak. Specifically, this study aimed to identify whether there are significant differences by gender for the leadership of the organization. Further, this study also wants to determine whether there is a positive and significant relationship between leadership and organizational commitment among teachers.

\section{Literature Review}

\subsection{Distributive Leadership}

Distributive leadership is a source of guidance and direction vary with expertise in the organization set up to improve teaching and school performance

Elmore (2000). In other words, leadership at school is a shared responsibility of all members of the organization in the school. Elmore (2000), also explains that there are four dimensions of distributive leadership namely leadership practices, vision and goal missions, school culture and shared responsibility. Distributive leadership does not mean to divert the principals' responsibility but principals play an important role in developing leadership in the 


\section{Sumerianz Journal of Education, Linguistics and Literature}

organization of members (Elmore, 2000). The results of Hermann (2016) suggest that the willingness of school leaders to distribute leadership has gained a lot of welcome. In fact, studies have shown that organizations are capable of building capacity and enhancing initiatives in improving teaching in schools through leadership distributions. Gordon (2005), states that the mission, vision and goals will be effective if all stakeholders are aware of their interests and missions, and the goals set forth must be clear, meaningful, useful and up-to-date. So, leaders who want to practice distributive leadership in schools want to ensure that their vision, mission and goals are up-todate, clear and meaningful. The distributive leadership contributed to the schooling and building the capacity of the school (Chen, 2007). This is a positive impact from distributive leadership that allows others to act and inspire a shared vision of achievement. Elmore (2000), also explains that there is no other way to perform complicated tasks without distributing responsibilities amongst those in the organization and without working hard to shape the same culture, symbol and ritual value. Consequently, guidance is needed from various specialists with a common culture. According to Sergiovanni (2000), culture is a normative sticker that holds a particular school together. School culture is the personality that affect the way schools work in school. To understand the culture of a school team, the characteristics of the same culture must be identified. By having the same cultural value, schools can achieve the mission through distributive leadership. Educators tend to be experts in areas of interest, talent, prior knowledge, skills and special roles (Elmore, 2000). Existing expertise improves the competence of educators and enables job responsibilities to be shared. Effective distributive leadership requires the ability to organize individuals with various competencies to complement each other. Spillane et al. (1999), also explained further important element in effective distributive leadership skills and responsibility is the need to expand the role of the staff rather than divided into different roles.

\subsection{Teacher's Organizational Commitment}

Meyer and Allen (1991), have defined organizational commitment as a psychological construct that involves the characteristics of labour relations with the organization and has implications for the individual's decision to continue work within the organization. Organizational commitment is a multi-dimensional construct comprising three components namely affective commitment, continuous commitment and normative commitment (Meyer and Allen, 1997). Affective commitment refers to emotionally bound employees, identification and involvement in the organization. Organizational members who are committed to the organization will continue to work for the organization for their own will. Workers abide by the values, objectives and values of the organization, thus forming employment relationships within the organization and keeping employees in the organization. Subordinates are more loyal to their respective organizations and are willing to go beyond the expectations of the organization. Employees enjoy their participation and are willing to serve the organization. The second dimension is continuous commitment. This continuing commitment focuses on commitments that are formed as a result of profit or loss considerations if leaving the organization due to the privileges or facilities it has acquired. Someone remains in the organization not because of their wishes but is due to the contribution given due to the time spent. These committed employees are more of a figure and are different from those with affective commitments where one remains in the organization for recognition of the organization and its values. Normative commitment is the obligation to continue work for the organization because of the pressure of others (Meyer and Allen, 1997). Wiener (1982), explains this normative commitment is an action that comes from internal normative pressure by way of meeting the goals and interests of the organization. The obligation to pursue work in the organization arises either through the process of socialization within the organization which causes employees to feel obligated to respond to organizations that benefit them (Meyer and Allen, 1991).

\section{Research Methodology}

\subsection{Research Design}

This research uses a quantitative approach by applying the cross-sectional survey based on a questionnaire answered by the respondent. Statistical inference is used to answer the research questions and draw conclusions about the relationship between distributive leadership and organizational commitment of teachers.

\subsection{Population and Sampling}

The population of this study consists of 1800 secondary school teachers in Kuching. A total of 18 secondary schools participated in the study. Simple random sampling has been used in this study. According to Krejcie and Morgan (1970) and Chua (2014) the number of samples as many as 317 respondents was randomly selected. The selected sample consists of academic teachers who are currently in secondary school.

\subsection{Research Instrument}

In this study, the instrument used consists of a set of questionnaire which contains three parts. Part A teacher seeks to gather demographic information. Subsequently, Section B contains 44 items used to identify the distributive leadership level of principals from four dimensions namely leadership practice, vision, mission and goals, school culture, and mutual responsibility. Part $\mathrm{C}$ consists of 24 items aimed at identifying the level of commitment of teachers' organizations through three dimensions namely affective commitment, continuous commitment and normative commitment. This questionnaire has been adapted from the Distributed Leadership Readiness Scale and Three-Component Model Employee Commitment Survey, each from the Education Connecticut State and Meyer et al. (1993). The 4 point Likert scale of 1 to 4 was used in this study. 


\subsection{Pilot Study}

This pilot study was conducted to determine the reliability and validity of the research instrument. The reliability of the instrument refers to the ability of the instrument to obtain a similar value when the same measurement is repeated (Chua, 2014). To measure the reliability of questionnaire items used, Alpha Cronbach method is used. A pilot study was conducted on 30 teachers (who were not involved as respondents of the study) to measure the reliability of the items in the questionnaire. Alpha Cronbach's analysis of both distributive leadership instruments and organizational commitment exceeds .90. Table 1 shows the reliability of instrument for pilot study.

Table-1. Reliability of the instruments in pilot study

\begin{tabular}{l|l|l|l}
\hline Part & Variable & Number of items & Cronbach's Alpha \\
\hline B & Distributive leadership & 44 & 0.946 \\
\hline C & Teacher's organizational commitment & 24 & 0.923 \\
\hline
\end{tabular}

\subsection{Data Collection Procedure}

Before the study was conducted at the school, the application was made from the Education Planning and Research Division, Ministry of Education Malaysia. Subsequently, apply for permission from the Sarawak State Education Department and the District Education Office, Kuching to conduct actual studies at selected schools in Kuching. Data collection through Google form has been run during the March until May 2019.

\section{Research Findings and Discussion}

A total of 317 respondents participated in this study where 72 respondents $(22.7 \%)$ were male respondents while $245(77.3 \%)$ were involved in the study. Based on the mean scores on each dimension of the principal distributive leadership, shared responsibility dimension achieved a mean score above 3.00 on a high level. Other dimensions including leadership practices, vision, mission, goals of the school and school culture occupied only a moderate level with a mean score of less than 3.00. Overall, the distributive leadership among the principals shown by the respondents was only moderate with a mean value of $2.96(\mathrm{SD}=0.36)$. Table 2 shows the mean score of each dimension according to the distributive leadership level of the principal.

Table-2. Mean and standard deviation of principal's distributive leadership $(\mathrm{N}=317)$

\begin{tabular}{l|l|l|l}
\hline Dimension & Mean & Standard Deviation & Level \\
\hline Leadership practices & 2.89 & 0.39 & Moderate \\
\hline Vision, mission and goals & 2.92 & 0.40 & Moderate \\
\hline School culture & 2.95 & 0.46 & Moderate \\
\hline Shared responsibilities & 3.04 & 0.39 & High \\
\hline Distributive leadership & 2.96 & 0.36 & Moderate \\
\hline
\end{tabular}

For teachers' organizational commitment, descriptive analysis has shown that the level of organizational commitment is moderate with a mean value of 2.58 ( $\mathrm{SP}=0.27$ ). The three dimensions of teacher organizational commitment have a mean value of less than 3.00. The findings also indicated dimension normative commitment has the highest mean score of 2.65. Table 3 shows the overall mean score for each dimension according to the organizational commitment level of the teacher. The findings are in line with Nurulaim and Suhaida (2013) study at Kangar secondary schools at a moderate level. Consequently, sharing responsibility is also identified as an indicator of distributed leadership approach being practiced and most dominant in school (Siva and Khuan, 2012).

Table-3. Mean and standard deviation of teacher's organizational commitment

\begin{tabular}{l|l|l|l}
\hline Dimension & Mean & Standard Deviation & Level \\
\hline Affective commitment & 2.51 & 0.33 & Moderate \\
\hline Continuous commitment & 2.59 & 0.39 & Moderate \\
\hline Normative commitment & 2.65 & 0.34 & Moderate \\
\hline Teacher's organizational commitment & 2.58 & 0.27 & Moderate \\
\hline
\end{tabular}

The findings of Table 3 shown normative commitment to occupy the most dominant place with a mean score of 2.65 at a moderate level. This is followed by continuing commitment and affective commitment. The finding is consistent with previous findings in which teachers' organizational commitment is moderate (Karakus and Aslan, 2009; Nurulaim and Suhaida, 2013; Yahzanon and Yusof, 2011). In addition, Asri (2007) studies show that the commitment of public sector employees is moderate. Accordingly, Marlia and Yahya (2016) explained that teachers are more committed normatively in the workplace. Employees with a strong normative commitment will survive their job due to obligations.

Table 4 shows the findings obtained from the t-test. The $t$-test analysis found that there was no significant difference in the level of organizational commitment between male respondents $(M=2.61)$ and female respondents $(\mathrm{M}=2.58)$ with $(t(315)=1.03, p>.05)$. The findings are in line with Marlia and Yahya (2016), Spillane et al. (1999), Rozi et al. (2016). Thus, gender is not a dominant factor on the commitment of teachers in schools. 
Sumerianz Journal of Education, Linguistics and Literature

Table-4. T-test analysis for teachers' organizational commitment by gender

\begin{tabular}{|c|c|c|c|c|c|c|c|c|}
\hline & \multirow[t]{2}{*}{ Gender } & \multirow[t]{2}{*}{$\mathbf{N}$} & \multirow[t]{2}{*}{ Mean } & \multirow{2}{*}{$\begin{array}{l}\text { Standard } \\
\text { Deviation }\end{array}$} & \multicolumn{2}{|c|}{ Levene Test } & \multirow[t]{2}{*}{ t value } & \multirow{2}{*}{$\begin{array}{l}\text { Sig. } \\
\text { (2-tailed) }\end{array}$} \\
\hline & & & & & $F$ & Sig & & \\
\hline \multirow{2}{*}{$\begin{array}{l}\text { Organizational } \\
\text { Commitment }\end{array}$} & Male & 72 & 2.61 & .29 & 1.80 & 0.18 & 1.03 & 0.30 \\
\hline & Female & 245 & 2.58 & .27 & & & & \\
\hline
\end{tabular}

Note:*Significant at $p<.05$ level

Table 5 shows the Pearson Correlation test results on the relationship between leadership distributive principals and teacher organization commitments. The analysis of this study showed a significant correlation $(r=.27, p<.05)$ between the principal distributive leadership and organizational commitment of teachers (Chua, 2014). This has shown that principals with high distributive leadership will bring high commitment among school teachers.

Table-5. Pearson correlation test on the relationship between leadership distributive leadership and teacher organization commitment

\begin{tabular}{l|l|l|l|l|l}
\hline & $\begin{array}{l}\text { Leadership } \\
\text { Practices }\end{array}$ & $\begin{array}{l}\text { Vision, } \\
\text { Mission, Goals }\end{array}$ & School Culture & $\begin{array}{l}\text { Shared } \\
\text { Responsibilities }\end{array}$ & $\begin{array}{l}\text { Distributive } \\
\text { Leadership }\end{array}$ \\
\hline $\begin{array}{l}\text { Organizational } \\
\text { Commitment }\end{array}$ & $.25^{* *}$ & $.23^{* *}$ & $.24^{* *}$ & $.24^{* *}$ & $.27^{* *}$ \\
\hline Affective & $.37^{* *}$ & $.35^{* *}$ & $.34^{* *}$ & $.31^{* *}$ & $.39^{* *}$ \\
\hline Continuous & $.13^{*}$ & .06 & $.16^{* *}$ & $.13^{*}$ & $.14^{*}$ \\
\hline Normative & .10 & $.14^{*}$ & .07 & $.13^{*}$ & $.12^{*}$ \\
\hline
\end{tabular}

Note: **Significant at $p<.05$ level *Significant at $p<.05$ level

In detail, the results of the analysis show a weak and significant correlation between affective commitment and dimension of leadership practices $\left(r=.37^{* *}, p<.05\right)$, vision, mission and goals $\left(r=.35^{* *}, p<.05\right)$, school culture $(r=.34 * *, p<.05)$ and shared responsibilities $\left(r=.31^{* *}, p<.05\right)$. For continuous commitment, the analysis also shows a very weak correlation with leadership practice $(r=.13, p<.05)$, school culture $(r=.16, p<.05)$ and shared responsibilities $(r=.13, p<.05)$. On the contrary, continuous correlation is found to have no significant relationship between vision, mission and goals. For normative commitment, analysis also shows a very weak and significant correlation to visions, missions and goals $(r=.14, p<.05)$ and shared responsibilities $(r=.13, p<.05)$. However, normative commitment has no significant relationship with leadership practices and school culture. This is in line with the findings of previous studies in which there is a significant relationship between distributive leadership and organizational commitment (Marlia and Yahya, 2016; Siva and Khuan, 2012). Accordingly, the study of Matthew (2016) also found significant moderate and positive relationships between distributive leadership towards affective commitments in public schools and private schools. Hence, the results of this study support distributive leadership as a way to increase affective commitment among teachers.

Distributive leadership practices in schools can build capacity and improve initiatives in school improvement (Hermann, 2016). Hence, the practice of distributive leadership is to increase affective, subordinate commitment to values, objectives and to establish employment relationships within the school organization and to remain in school. According to Gordon (2005), the mission, vision and goals to be effective if all stakeholders are aware of its importance and mission, and goals should be clearly defined, meaningful, useful and up to date. Meanwhile, the findings show that there is a significant influence on the vision, mission and goal towards normative commitment of teachers. Teachers who have normative commitments have the compulsory feeling of continuing their work for school due to external pressure (Meyer and Allen, 1997). Wiener (1982), also explains this normative commitment is an action that comes from internal normative pressure in order to fulfil the goals and interests of the organization. This description is parallel to the findings of the study, where vision, mission and goals contribute to the normative commitment of teachers.

\section{Conclusion}

This study has identified distributive leadership and organizational commitment respectively at a modest level. Thus, the present leadership should be more flexible and focused on sharing power. The trend of today's leadership of education is no longer seeing principals taking all responsibility as school leaders. An old look at the leadership of a school where one of the best leaders was at the top of an organization (Hulpia et al., 2009) was no longer acting alone in achieving success in the organization in line with the recent rapid educational reforms. School management and administration today requires the involvement of all teachers in certain leadership aspects according to their own talents and skills. It is therefore important for principals to extend the role of teachers according to the teacher's expertise so that organizational commitment can be enhanced. This is because the positive results of the organization's commitment to higher job satisfaction, the lower level of staff influx, the minimum absence, the improvement of organizational membership behaviour and the improvement of student achievement (Chan et al., 2008). With the positive outcome of this commitment, excellence and school effectiveness are guaranteed.

\section{References}

Asri, M. H., Abdul. Latip. (2007). Faktor-faktor mempengaruhi komitmen pekerja di organisasi awam. Jurnal Kemanusiaan, 5(2): 1-9.

Billingsley, B. S. and Cross, L. H. (1992). Predictors of commitment, job satisfaction, and intent to stay in teaching: A comparison of general and special educators. Journal of Special Education, 25(4): 453-71. 


\section{Sumerianz Journal of Education, Linguistics and Literature}

Chan, W. Y., Lau, S., Nie, Y., Lim, S. and Hogan, D. (2008). Organizational and personal predictors of teacher commitment: The mediating role of teacher efficacy and identification with school. American Educational Research Journal, 45(3): 597-630.

Chen, Y. H. (2007). Principals' distributed leadership behaviors and their impact on student achievement in selected elementary schools in Texas. (Unpublished doctoral theses). A and M University: Texas.

Chua, Y. P. (2014). Asas statistik penyelidikan. 3rd Ed edn: McGraw-Hill: Shah Alam.

Elmore, R. F. (2000). Building a new structure for school leadership. The Albert Shanker Institute.

Gordon, Z. V. (2005). The effect of distributed leadership on student achievement. Central Connecticut State University: New Britain, CT.

Gronn, P. (2000). Distributed properties: A new architecture for leadership. Educational Management and Administration, 28(3): 317-38.

Harris, A. and Spillane, J. (2008). Distributed leadership through looking glass. Management in Education, 22(1): 31-34.

Hermann, K. R. (2016). The Principal's role; Distributed leadership. (Unpublished doctoral theses). Old Dominion University.

Hulpia, H., Devos, G. and Rosseel, Y. (2009). The relationship between the perception of distributed leadership in secondary schools and teachers' and teacher leaders' job satisfaction and organizational commitment. International Journal of Research, Policy and Practice, 20(3): 291-317.

Ingvarson, L., Anderson, M., Gronn, P. and Jackson, A. (2006). Standard for school leadership: A critical review of literature. Australian Institute for Teaching and School Leadership: Acton.

Karakus, M. and Aslan, B. (2009). Teachers commitment focuses: A three-dimensioned view. Journal of Management Development, 28(5): 425-38.

Krejcie, R. V. and Morgan, D. W. (1970). Determining sample size for research activities. Educational and Psychological Measurement, 30(3): 607-10.

Leithwood, K. and Jantzi, D. (2000). The effects of transformational leadership on organizational conditions and student engagement with the school. Journal of Educational Administration, 38(2): 112-29.

Marlia, J. and Yahya, D. (2016). Praktis kepimpinan distributif dan komitmen terhadap organisasi berdasarkan kohort generasi guru. Proceeding of ICECRS, 1(1): 275-86.

Matthew, J. T. (2016). The relationship between distributed leadership and teacher affective commitment in public and private schools. (Unpublished doctoral theses). Carson-Newman University.

Meyer, J. P. and Allen, N. J. (1991). A three-component conceptualization of organizational commitment. Human Resource Management Review, 1(1): 61-89.

Meyer, J. P. and Allen, N. J. (1997). Commitment in the workplace, theory, research and application. Sage: California.

Meyer, J. P., Allen, N. J. and Smith, C. A. (1993). Commitment to organizations and occupations: Extension and test of a three-component conceptualization. Journal of Applied Psychology, 78(4): 538-51.

Nurulaim, A. and Suhaida, A. K., 2013. "Komitmen organisasi terhadap sekolah menengah di daerah Kangar, Perlis." In Kertas pembentangan dalam Seminar Pasca Siswazah dalam Pendidikan. Universiti Putra Malaysia.

Rozi, M., Abd Latif, K., Sofiah, Z. and Faezah, M. N. (2016). Komitmen guru dan kepuasan kerja di sekolah menengah harian berprestasi tinggi dan berprestasi rendah di daerah Kota Bharu, Kelantan`. Proceeding of ICECRS, 1(1): 863-74.

Sergiovanni, T. J. (2000). Changing change: Toward a design science and art. Journal of Educational Change, 1(1): $57-75$.

Siva, R. and Khuan, W. B., 2012. "Hubungan kepemimpinan distributif terhadap komitmen: Organisasi dan tekanan kerja dalam pendidikan teknik dan vokasional." In National Research and Innovation Conference for Graduate Students in Social Sciences.

Spillane, J. P., Halverson, R. and Diamond, J. B. (1999). Distributed leadership: Toward a theory of school leadership practice. Annual Meeting of the American Educational Research Association: Montreal.

Timperly, H. S. (2005). Distributive leadership: Developing theory from practice. Journal of Curriculum Studies, 37(4): 395-420.

Wiener, Y. (1982). Commitment in organizations. A normative view. Academy of Management Review, 7(3): 41828.

Yahzanon, T. and Yusof, B. (2011). Tahap kecerdasan emosi dan hubungannya dengan komitmen guru dalam bekerja dalam kalangan guru mata pelajaran teras tahun enam. Journal of Edupres, 1(2011): 87-196. 